\title{
Choosing the flow part geometric shape of the dredge pumps for viscous fluids
}

\author{
Guldana Akanova ${ }^{1 \otimes(\odot)}$, Laila Sagatova ${ }^{1 * \otimes(\odot)}$, Lazizjon Atakulov ${ }^{2 \otimes(\odot), ~}$ \\ Umid Kayumov $^{2 \otimes(D)}$, Muhammad Istamov ${ }^{2 \otimes(D)}$ \\ ${ }^{1}$ Satbayev University, Almaty, 50013, Kazakhstan \\ ${ }^{2}$ Navoi State Mining Institute, Navoiy, 210100, Uzbekistan \\ *Corresponding author: e-mail laila-sagatova@mail.ru, tel.+77018619210
}

\begin{abstract}
Purpose. Search for the possibility of increasing the efficiency of dredge pumps for viscous fluids by determining the rational values of the blade-outlet inclination angles in the pump impellers.

Methods. During the research, the following is used: theoretical studies of the structure of the viscous fluids flowing through the flow part of dredge pumps; the method of three-dimensional software-simulation modeling of hydrodynamic processes using the Ansys software package; the methods of rational experiment planning for selecting the values of the number of points in the computational grid when optimizing the geometric parameters of the dredge pump impellers; methods of mathematical statistics and correlation analysis.

Findings. It has been proven that the main reason for the failure of the flow part components in the dredge pumps is the manifestation of the influence of cavitation processes, which can be eliminated by changing the blade-outlet inclination angles in the pump impellers. A software-simulation complex for the automated design of the flow parts in the dredge pumps has been developed based on the use of optimization algorithms and computational fluid dynamics methods, which makes it possible to design dredge pumps with optimal characteristics that ensure their efficient operation with maximum efficiency values. It has been determined that one of the main factors influencing the head developed by dredge pumps and the efficiency value is the blade-outlet inclination angle in the pump impellers.

Originality. Scientific novelty is in the scientific substantiation and development of a simulation-mathematical method for calculating the geometric parameters of the flow part in dredge pumps for viscous fluids at the design stage.

Practical implications. The developed method for determining the rational blade-outlet inclination angles of the impellers in the dredge pumps for viscous fluids can be recommended to scientific-research and industrial organizations for use in the improvement, design and operation of the dredge pumps.
\end{abstract}

Keywords: hydraulic transport, dredge pump, impeller, blade, wear, static pressure

\section{Introduction}

One of the priority tasks for the mining enterprise is to increase the operated equipment efficiency, including the creation of a transport base of high performance with a significant reduction in the cost of transporting the mineral raw materials and products of their processing. This task is especially relevant for hydraulic pipe-line transport, with the help of which more than 2 billion tons of various solid bulk materials, mainly tailings of mineral raw materials and concentrates, are transported in the CIS countries annually. Therefore, design and production enterprises face new challenges in the development and implementation of the most efficient hydraulic transport systems and reduction of energy and capital costs [1].
The problem of increasing the dredge pump efficiency is currently one of the most urgent. A large number of studies developed by leading domestic and foreign experts, research organizations are devoted to the parametric analysis of the hydraulic characteristics of dredge pumps for viscous fluids, as well as to the issue of increasing their reliability.

The task of determining the flow part geometric shape of the dredge pumps undoubtedly has several isolated ways of solution. Based on this, to date, several main research directions have been formed in this area, dealing with the issues of design and development of new flow parts of impellers and internal casings of dredge pumps using special computer programs and numerical approaches to modeling in order to improve the flow part geometry, increase in the efficiency and energy performance of pumps. 
This direction includes studies devoted to the numerical simulation of unsteady flows in dredge pumps [2], [3]. They give a formalized approach to determining the internal energy dissipation during the rotation of a dredge pump impeller under conditions of its operation with a partial load caused by separation and stalls of the flow. The main purpose of the studied models is to predict the head loss in a dredge pump operating with several particle sizes from 0.1 to $5 \mathrm{~mm}$ and various solid phase volumetric concentrations from 20 to $30 \%$. It is noted that the presented model can be a useful tool for analyzing existing dredge pumps or for designing new machines.

The work [4] is of interest, as it represents a modeling method without a grid. This is a method of smooth part hydraulics (SPH), which lays the foundation for threedimensional modeling of the internal flow and transient process of the dredge pump. It is noted that it is very useful for identifying the internal unsteady mechanism of the flow system transient process in the centrifugal dredge pump, which is of great theoretical importance for ensuring reliable and stable operation of the dredge pumping system.

In the works [5], [6] the authors model and analyze the movement trajectories of sediment particles with various sizes in a dredge pump based on sliding grids and the Lagrangian method. In addition, they predict the area and the intensity of wear of the impeller and casing in accordance with the erosion model. It is noted that the flow in the dredge pump is complex, three-dimensional and unstable. Due to the difference in density between the sediment particles and the fluid feeder, the solid particles deflect from the surrounding flow with different directions of movement and velocity under the impact of inertia. Thus, particle deflection leads to change in hydraulic characteristic, efficiency and durability of the pump. The calculated result is consistent with dredge pump wear occurrence in practical engineering applications.

This work presents a research devoted to the energy dissipation as a result of the phenomenon of unsteady flow inside a three-blade impeller of a dredge pump under conditions of its operation with overload, which is of considerable interest [7], [8]. In this case, a 3D unsteady numerical simulation of the dredge pump is performed using the SAS SSI turbulence model with curvature correction and total energy equation. As a result of unsteady modeling, it has been determined that a high-energy turbulent flow is periodically generated and flaked away, which causes losses of hydraulic energy in conditions of operation with overload.

In practice, dredge pumps are usually exposed to highdensity water-sand mixture, which has a large impact on pump service life. To get an idea of the wear resistance of the dredge pump working elements, it is necessary to know the mixture flow characteristics. In the work [9], [10], the authors analyze the behavior of the water-sand mixture flow in a typical dredge pump. For this purpose, the so-called drift flow model is used, in which the Reynolds-averaged NavierStokes equations (RAHC) are solved for a water-sand mixture. The numerical simulation results are in good agreement with the experimental values, and the predicted pump performance degradation is in conformity with the ANSI/HI standard for the sludge pumps.

Analysis of works aimed at the study of hydroabrasive wear of the dredge pump flow parts, in general, reveals an increased interest in this problem. It should be noted that due to the lack of a unified theory of hydroabrasive wear of the dredge pump working surfaces, these studies are developing due to the accumulation and multiplication of the research results of various types of abrasive and surface wear. Thus, in the work [11], the dependence of the wear rate of the impeller and the volute surfaces on the sediment concentration is studied using the wear rate distribution. The EulerLagrange computational fluid dynamics (CFD) procedure is used to simulate steady-state two-phase fluid-solid flow for various operating conditions of the pump. The FINNIE model is developed to predict the abrasion of the impeller and volute surfaces. It has been determined that the relative wear rate for the casing surface is greater than for the impeller surface, and the relative value for the flow parts is low in the area of high pump efficiency.

In the work [12], the authors study the dependence of the wear rate of the impeller and the casing surfaces on the sediment concentration, while analyzing the wear rate distribution for normal operating conditions of the pump. The EulerLagrange computational fluid dynamics (CFD) procedure is used to simulate steady-state two-phase fluid-solid flow for various operating conditions of the pump. Then, the FINNIE model is used to predict the abrasion. The results indicate that the relative value of the impeller wear rate increases with increasing sediment concentration. The relative value of the wear rate of the impeller and the casing surface is greater when the pump is in a low flow rate state and the value of the casing surface is greater than that of the impeller.

The methods for designing the dredge pump impellers are described in the works [13]-[15]. They present the mathematical models used to numerically study stiffness and damping in the analysis of the dynamics of pump designs, and which are the basis for their design. Having combined an operating experience and the latest developments in the field of pumping technology, a new type of impeller has been developed the "curved impeller". This new type of impeller can be used in existing high-efficient pumps without any modifications and can provide better suction performance and lower wear characteristics of the dredge pump impeller.

This trend includes the studies [16]-[18], devoted to methods of regulating the dredge pumps functioning in the operating range. The authors emphasize that the information obtained from the output variables in the dredge pump made it possible, based on statistical analysis, to develop mathematical correlations that allow directly identifying the relationships between the process variables and their influence on pump behavior (suction and discharge pressures, total dynamic head, NPSHr and efficiency). The results obtained show that the simulation process allows for a high prediction in relation to the actual operating conditions of the pump (error less than 4\%). Mathematical ratios have shown efficiency for an operating range from 83 to 64\%. In addition, the NPSHr analysis enables determination of operating range to avoid adverse effects such as cavitation.

Despite the significant amount of research on this issue, the problem of choosing the geometric shape of the flow part in the dredge pumps for viscous fluids is still not comprehensively solved. A comprehensive solution to the problem of increasing the energy efficiency of dredge pumps requires not only the structural improvement of the flow part, but also the rationalization of the pumping equipment operating modes.

To solve these problems, design organizations are required to perform a thorough calculation of all technological parameters of the production process and the selection of 
technological equipment. This is especially true for the selection of dredge pumps, for which optimal mode of operation is a determining factor affecting the service life and energy efficiency of pumping systems. In practice, when choosing a dredge pump, designers and equipment suppliers rarely think about the processes occurring in the pumped hydraulic fluid and the flow part of dredge pumps. The determining factors when choosing dredge pumps are the values of delivery rate, head, electric power consumption, efficiency. This approach, when choosing the dredge pumps for pumping hydraulic fluids with different concentrations and sizes of solid particles, is conditioned by the fact that the largest volume of pumps produced are $\mathrm{m}$ marked arked in accordance with the developed parametric series [19]. This parameterization is based on the type and parameters of the pump (flow rate and head). The division of dredge pumps into a parametric series leads to the fact that the designer is not able to include in the project a dredge pump with the parameters required for technological equipment.

The selection of the dredge pump according to the principle "closest in terms of parameters" in the direction of increase, but with a maximum excess of no more than $10 \%$, and taking into account the incorrect determination of the hydraulic characteristics of the system, it can give an error in determining the parameters of dredge pumps from 15 to $20 \%$. This situation has led to the fact that at the enterprises of the mining and metallurgical sector of the CIS countries, about $60 \%$ of dredge pumps operate in non-optimal modes, with increased electric power consumption, wear of the flow part components. As a result, this requires significant costs for operation and maintenance [20].

The use of dredge pumps in non-optimal modes leads to the occurrence of recirculation at the inlet and outlet of the pump, abrasive wear at the inlet and outlet edges of the impeller, the rear plate and the walls of the inner casing. The consequences of this wear are increased vibration, a drop in pump performance, a decrease in efficiency and an increase in electric power consumption.

Due to the end of service life and obsolescence of technological equipment, at present the main reason for failures in the operation of hydraulic transport systems is the low mechanical reliability of working devices. For this reason, up to $80 \%$ of accidents and equipment failures occur, a third of which are caused by dredge pumps [21].

The wear of the impellers, in turn, causes significant vibrational stresses transmitted to the supporting nodes of the pumping unit - bearings, the service life of which is sharply reduced and leads to a decrease in efficiency [22].

Significant hydroabrasive wear of pump components is a consequence of the high abrasive properties of the pumped medium. It is important to note that the factors that are a consequence of hydroabrasive wear of the main elements of the hydraulic transport system and ultimately lead to its failure have not been sufficiently studied. In addition, the typical causes of failures are poor-quality seals, imperfect design of the impeller fixture to the pump shaft and bearing assemblies, as well as the lack of a system for diagnostics and monitoring of the equipment condition during operation.

The purpose of this work is to increase the energy performance of dredge pumps by modifying and optimizing the profiling of the pump flow part with an increase in the hydraulic and volumetric efficiency.
The main objective is to determine the rational values of the blade-outlet inclination angles of the pump impellers. The choice of rational values of the outlet inclination angles can only be made by comparing a sufficient number of alternatives. However, it should be noted that the determining parameter for their selection is the condition for achieving the maximum efficiency value.

The optimization problem formulation includes the synthesis of the impeller profile in the dredge pump flow part based on the classical problem of the calculus of variations using three-dimensional simulation modeling by determining the path of a viscous fluid particle motion from point $\mathrm{A}$ to point B with minimal costs. The main parameters that determine the dredge pump blade geometry are the angles of setting the blade in plan at the inlet and outlet, taking into account the achievement of the displaceable and static pressure values at the inlet and outlet at a given impeller rotation velocity and the maximum value of efficiency.

\section{Methods}

The results of the analysis of domestic and foreign methods for calculating the hydraulic transport and the choice of dredge pumps make possible to conclude that today there are no generally accepted methods and recommendations for the design of hydraulic transport. Existing methods and manuals for calculating the hydraulic transport are either designed for limited operating conditions, or they cannot evaluate and calculate all the necessary characteristics of the hydraulic system to assess the dredge pump operating modes, as well as to analyze its wear.

In this work, a method is taken of software simulation modeling of fluid flow processes in the dredge pump impeller with the use of the Ansys software package, which makes it possible to determine the rational values of the blade-outlet inclination angles in the dredge pump impeller, depending on the pressure values at the inlet and outlet in order to increase the pump efficiency.

The design of the dredge pump is given in Figure 1. The pump operates in the following way: the pumped mixture enters the impeller through the throat of the cylindrical suction element for the slurry inlet. Further, through the operation of the wheel blades, the hydraulic fluid is fed into the discharge pipeline, which entrains the slurry through the action of centrifugal forces.

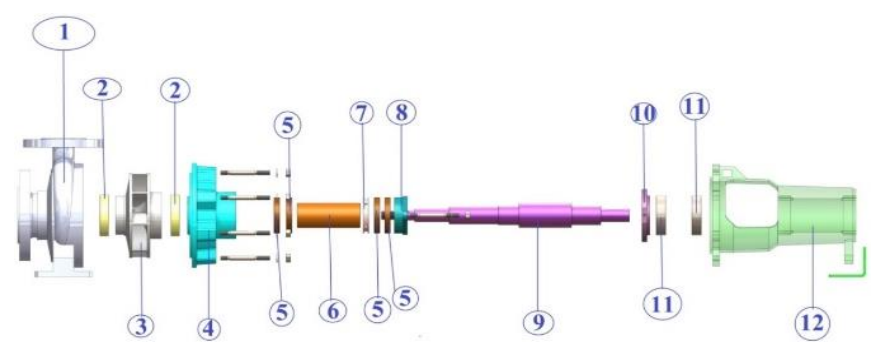

Figure 1. Dredge pump structural design: 1-pump casing; 2 -ring (volute); 3 -impeller; 4-coupling; 5 -gland seal; 6 -gland pocket; 7 - pump lantern ring; 8 -gland seal pocket; 9 -shaft; 10 -bearing cap; 11 -bearing; 12 - cast bracket

An open impeller (Fig. 2) consists of one disc and blades located on its surface. The number of blades in such impellers is most often either four or six. They are very often used where 
a low head is required, and the working medium is polluted or contains oily and solid inclusions. This wheel structure is convenient for cleaning its channels. The efficiency of open wheels is low and is approximately no more than $40 \%$ [23].

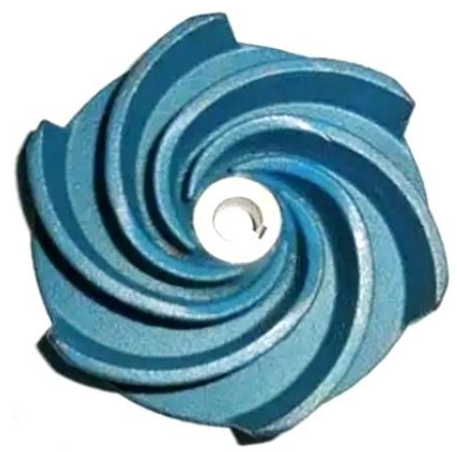

Figure 2. Impeller type

The impeller is the main working element of the pump, since it is the impeller blades that transfer mechanical energy to the fluid. The correct choice of material for the pump impeller ensures high working efficiency.

Often, the main cause of impeller breakage is cavitation, that is, vapor generation and the formation of vapor bubbles in the fluid, which entails metal erosion, since the fluid bubbles contain the gas chemical aggressiveness [24].

The cavitation process is often the main negative factor (Fig. 3), which leads to serious partial erosion and wear of the flow parts in the cavitation zone and, hence, to the rapid failure of the dredge pump flow parts [25], [26].
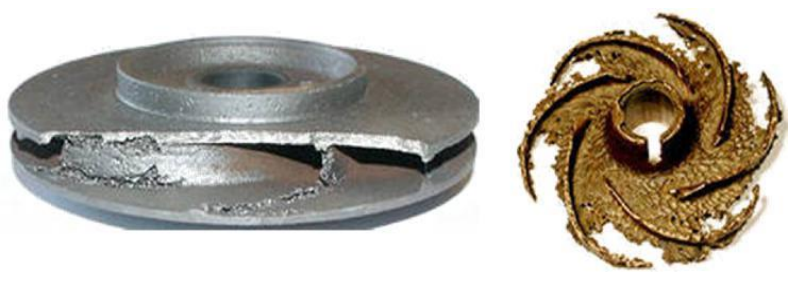

Figure 3. Signs of impeller breakage due to cavitation

Cavitation is a complex set of the following phenomena:

- release of vapor and dissolved gases from a fluid;

- local increase in fluid movement velocity;

- condensation of vapor bubbles entrained by the fluid flow in the area of increased pressure;

- chemical metal destruction in a cavitation zone by oxygen from air released from a fluid when it passes through zones of low pressure.

The ranges of regulating the cavitation process are limited by the rotation of the guide blades, since the angle between the direction of the jet and the guide blades is very small. The above problems can be solved by changing the blade-outlet inclination angles on the impellers in the dredge pumps.

When optimizing the geometric shape of the flow parts of different types of pumps, it is necessary to consider different optimization criteria. To obtain the values of the optimization criteria with the specified parameters, the method of threedimensional modeling of hydrodynamic processes in the pump working cavity is used with various model settings, which makes it possible to solve the set optimization problem with minimal consumption of computing resources in the Ansys software package.
Currently, the methods of profiling the pump impellers based on software systems, in particular, using the Ansys software package, are the most widespread. The method is based on modeling the fluid flow in the pump impeller. A fragment of the pump impeller model is shown in Figure 4 [27].

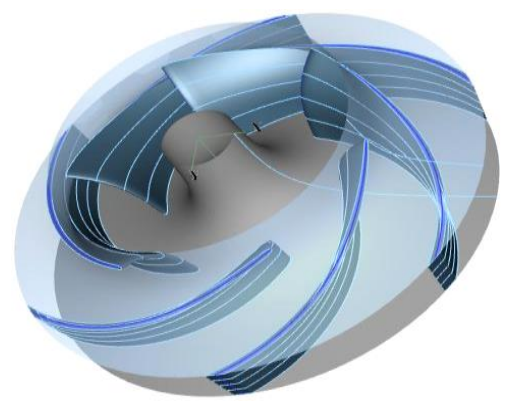

Figure 4. Pump impeller when simulated in Ansys

Despite the simplicity and computational efficiency, all classical calculation methods require high qualifications of the calculator and rich experience in profiling the dredge pumps to achieve a positive result. Failure to take into account the full structure of the viscous fluid flow in the dredge pump flow part does not allow revealing the influence of many geometric factors on the pump parameters. These include a change in the angle of the pump blade setting along the channel, the angle of the blade sweep, the diffuseness of the channels of the diverting devices, which does not allow formulating an unambiguous conclusion about the improvement of the dredge pump characteristics.

With the advent of computers capable of high-speed data processing, sufficient to perform hydrodynamic modeling, this method of calculating the hydraulic machines is rapidly developing. Numerical experiment has many advantages over other research methods. First of all, numerical simulation can significantly reduce the cost of conducting a large number of full-scale experiments, because after verification of the mathematical model, it can be used many times without resorting to a physical experiment [28].

The Ansys software package makes it possible to automate the design process of the impeller flow parts, guiding apparatus and diverting devices of centrifugal and axial pumps. The following figures show fragments of the Ansys program interface for impeller profiling (Fig. 5).

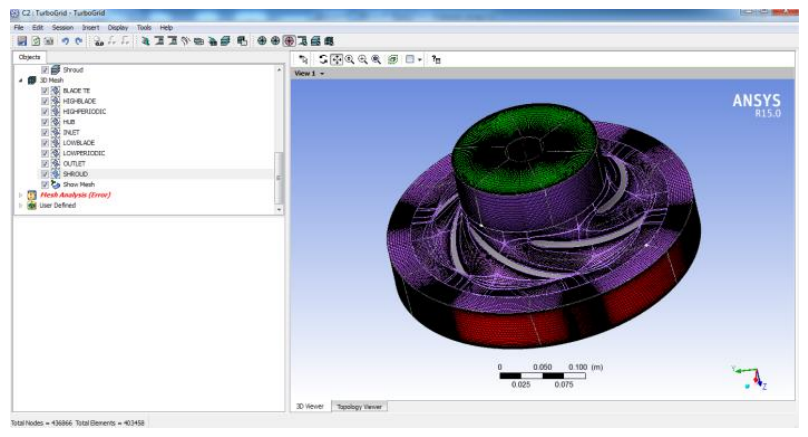

Figure5. 3D model of an impeller developed in the Ansys package (TurboGrid)

The calculations are made for the dredge pump as a whole, but only the impeller is parameterized (Fig. 6). When calculating the pumps with a simple flow part shape, this approach is more effective [29]. 
(a)

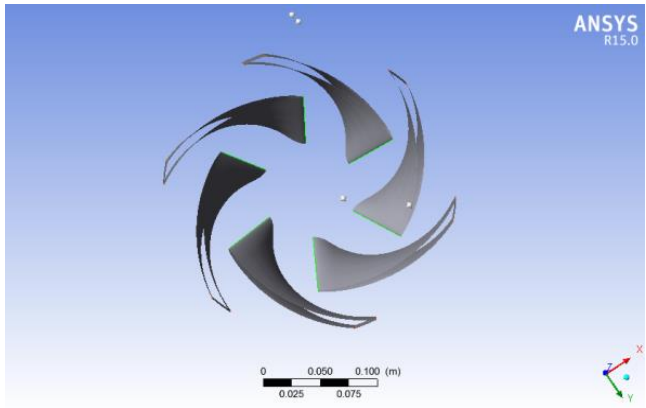

(b)
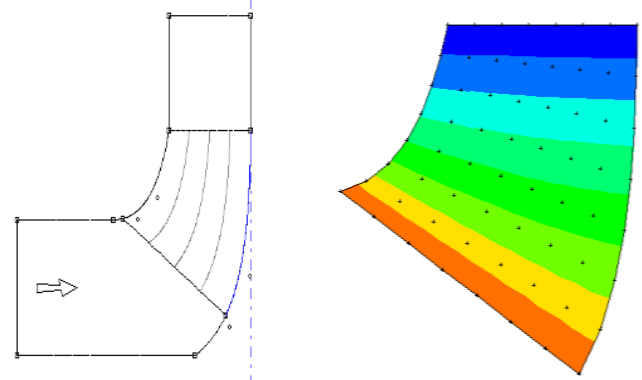

Figure 6. Optimized and original impeller geometrical shape: (a) 3D view; (b) blade profile; (c) meridian view

The choice of the computational grid parameters is critically important when optimizing the flow part. The number of computational cells directly affects the calculation time, and, hence, the duration of the entire optimization process. The greatest accuracy can lead to a significant increase in the time of the entire optimization, and in the end the whole work can become meaningless (Fig. 7) [30].

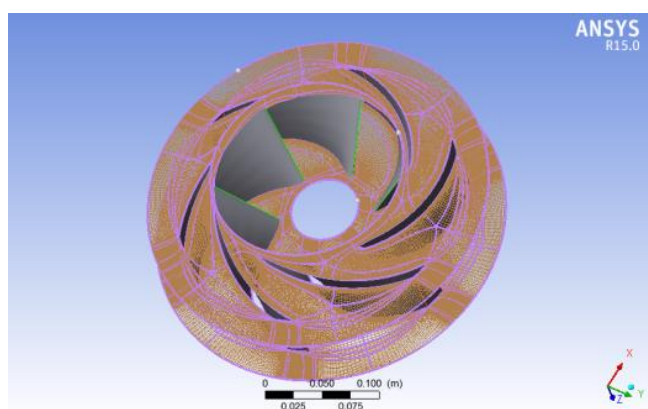

Figure 7. An example of a computational grid

The choice of the computational grid parameters is a rather creative process. However, the studies performed in this work make it possible to form general recommendations for obtaining a rational number of computational cells that are acceptable for optimizing the dredge pump impellers.

First of all, it is necessary to determine the total number of the computational grid points. To perform the necessary optimization for determining a rational number of computational grid points, the test results of the dredge pump are compared with the modeling results on grids of different sizes (Fig. 8).

It should also be noted that when calculating many impeller types, it is possible to significantly save computing resources by correctly choosing the grid size for various impeller elements [31]. (a)
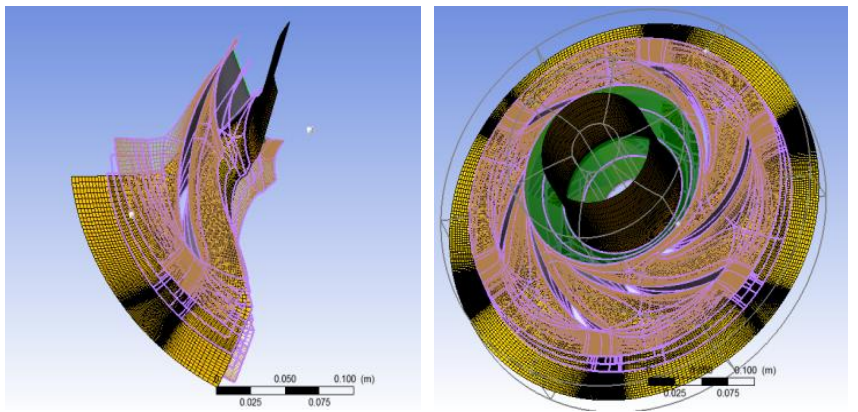

Figure 8. Computational grid with 436866 cells

Typically, the pump impeller flow part occupies a significantly smaller volume in space than the diverting and feeding devices, which allows the use of a smaller grid size than in the rest of the impeller.

When optimizing the flow part individual elements, it is possible to increase the number of cells to the same order as when calculating the dredge pump as a whole. Because, when the number of grid cells is less than 1 million, the computer time spent on calculation and optimization is much less than the time spent on processing and analyzing the results.

To reveal the dependence of the impeller parameters at the inlet and outlet of the dredge pump on the pressure change, calculations are performed using the Ansys software package.The calculations are made for a pump with parameters: pump delivery rate $Q=400 \mathrm{~m}^{3} / \mathrm{h}$, head $H=32 \mathrm{~m}$ and rotation frequency $\mathrm{n}=2000 \mathrm{rpm}$. The blade-outlet angle of the impeller is $\beta \pi_{2}=58.18^{\circ}$ (Fig. 9). The research purpose is to test the calculation methods for determining the rational value of the blade-outlet inclination angle in the pump impellers $\left(\beta \pi_{2}\right)$ to increase the pump efficiency. (a)

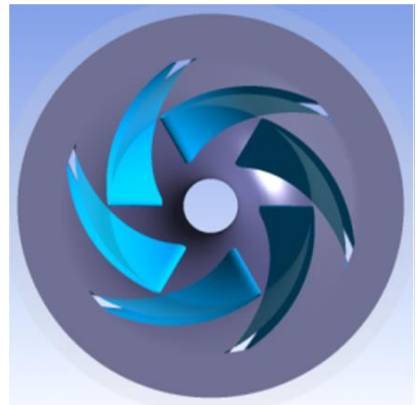

(c)

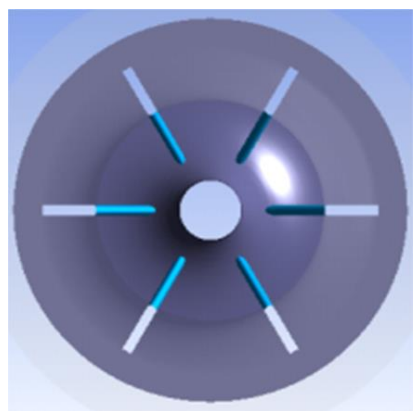

(b)

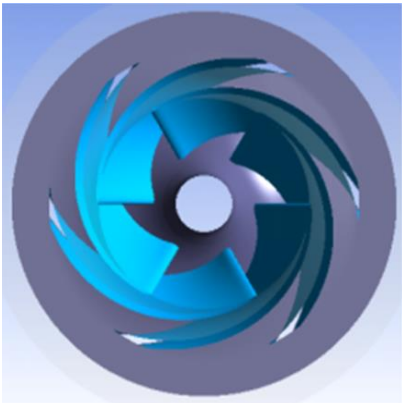

(d)

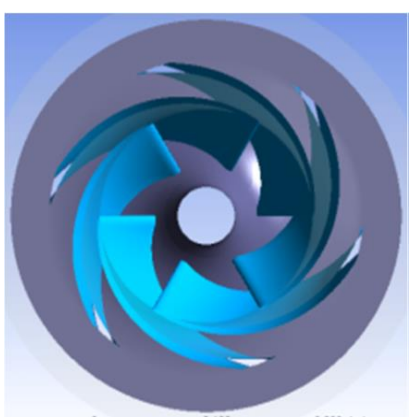

Figure 9. Impellers: at the angle of the blades: (a) $\beta \pi_{2}=58.18^{\circ}$; (b) $\beta \pi_{2}=50.1^{\circ}$; (c) $\beta \pi_{2}=90^{\circ}$; (d) $\beta \pi_{2}=121.24^{\circ}$ 
The developed calculation method based on optimization algorithms using the Ansys software package makes it possible to select rational angles of setting the impeller blades of the dredge pump, taking into account the pressure values at the inlet and outlet. The calculations take into account the values of the angles of setting the blades from $90^{\circ}$ to the maximum curvature, as well as obtaining the total $P_{t}$ and static pressure $P_{s}$ at a given velocity of the impeller rotation. In some cases, when a large head is required, the angle $\beta \pi_{2}$ can be selected up to $\beta \pi_{2}>90^{\circ}$ however, this reduces the impeller efficiency.

\section{Results and discussion}

The use of large inclination angles of the impeller blades $\beta \pi_{2}>90^{\circ}$ is limited due to an increase in losses in the diverting diffuser devices, since in this case the share of the dynamic head, which is converted in these devices into static pressure, greatly increases (Fig. 10c, d).

As can be seen from the graphs above, if we change the angles of the blades, both static and total pressure are changed (Fig. 10). If we increase the inclination angle of the blades on the impellers, the static pressure $P_{s}$ increases, so the total pressure $P_{t}$ decreases (Fig. 10c, d). If we set the inclination angle of the blades on the impellers equal to $\beta \pi_{2}=50.1^{\circ}$ as shown in Figure $10 \mathrm{~b}$, the static pressure $P_{s}$ decreases, and the total pressure $P_{t}$ increases.

Analysis of the calculation results shown in Figure 11 indicates that at the blade-outlet inclination angles of the impeller $\beta \pi_{2}=50.1^{\circ}$, the performance of the dredge pump is higher than at other blade-outlet inclination angles of the impeller $\left(\beta \pi_{2}=58.18^{\circ}, \beta \pi_{2}=90^{\circ}\right.$ and $\left.\beta \pi_{2}=121.24^{\circ}\right)$.

The calculation results indicate that with an increase in the blade-inlet inclination angle, the efficiency of the impeller decreases. And with an acute angle of the blade-inlet, the impeller efficiency increases (Fig. 12).

Therefore, it can be stated from Figure 12a, that with an increase in performance, efficiency decreases (in red), the head increases cyclically (in blue), and from Figure 12b, on the contrary, with an increase in performance, the efficiency becomes higher, but the head decreases.

The graphical results of analysis obtained in the Ansys software package confirm that the error when calculating the main impeller parameters with the number of computational cells up to 500 thousand is no more than $5 \%$, which is quite acceptable when performing the optimization calculations.

Calculation of one model with the number of computational cells up to 500 thousand, even in an unsteady setting, takes only a few hours, which is quite acceptable for solving the problems of optimal design.

The results of the research performed make it possible to conclude that the error of the obtained results of numerical experiment in comparison with the full-scale experiment is no more than $1-5 \%$ both when calculating the head characteristic and when calculating force factors, such as the rotary torque, radial and axial loads on the pump impeller. This allows using the data of a numerical experiment at the stage of designing a dredge pump.

Thus, it can be noted that one of the main factors influencing the performance of dredge pumps is the blade-outlet inclination angle of the impellers. The high-speed impeller, through the use of an improved diverting device, allows achieving its maximum energy efficiency. (a)

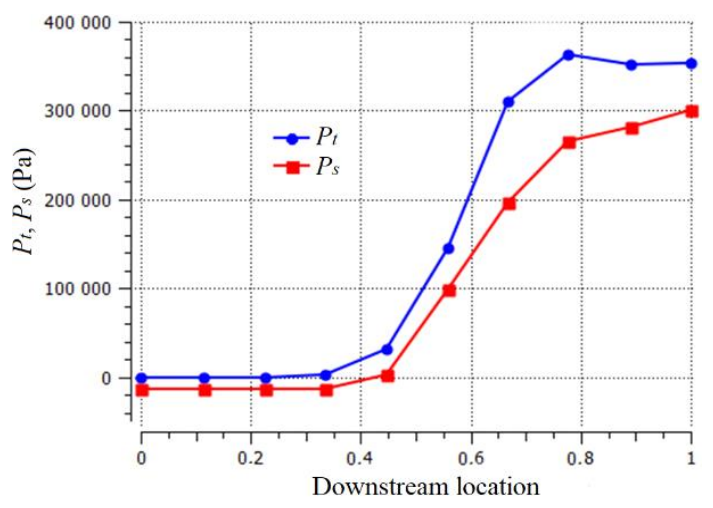

(b)

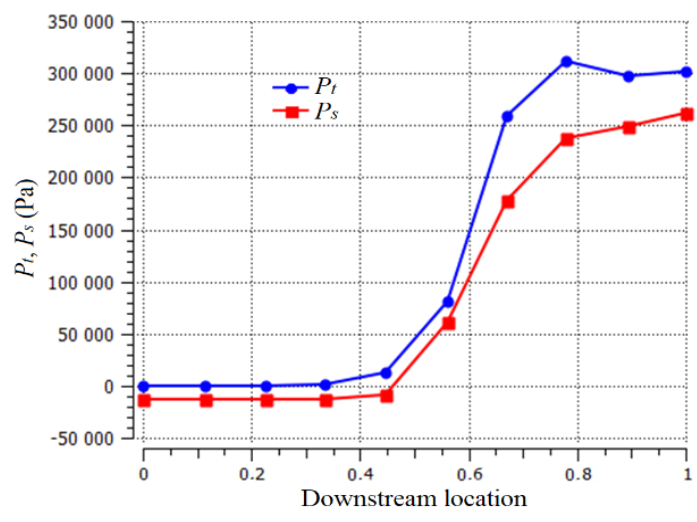

(c)

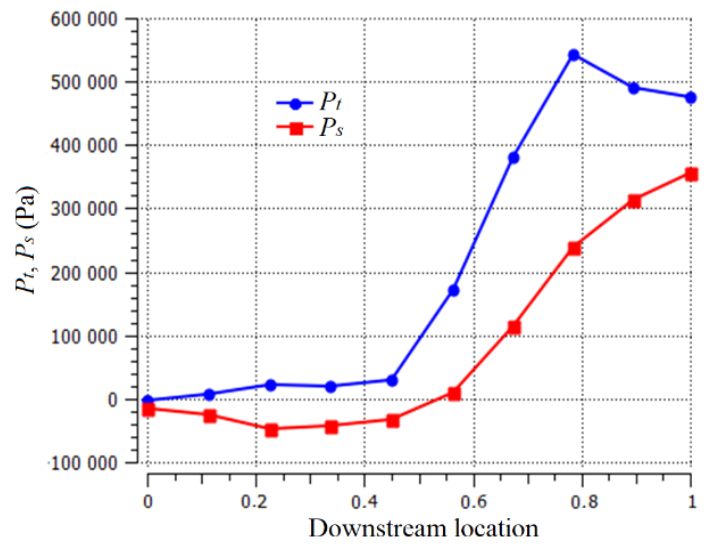

(d)

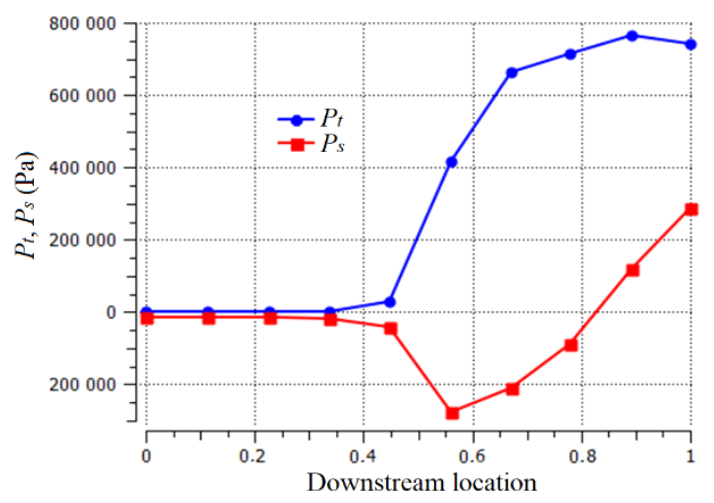

Figure 10. Static and total pressure: at the angle of the blades: $\quad$ (a) $\beta \pi_{2}=58.18^{\circ} ; \quad$ (b) $\beta \pi_{2}=50.1^{\circ} ; \quad$ (c) $\beta \pi_{2}=90^{\circ}$; (d) $\beta \pi_{2}=121.24^{\circ}$ 
(a)

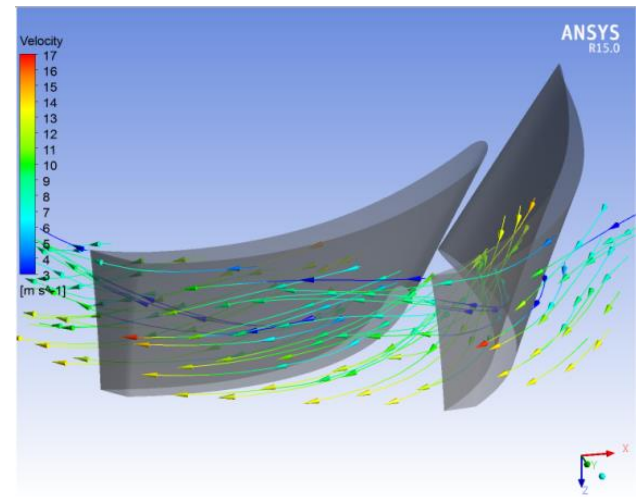

(b)

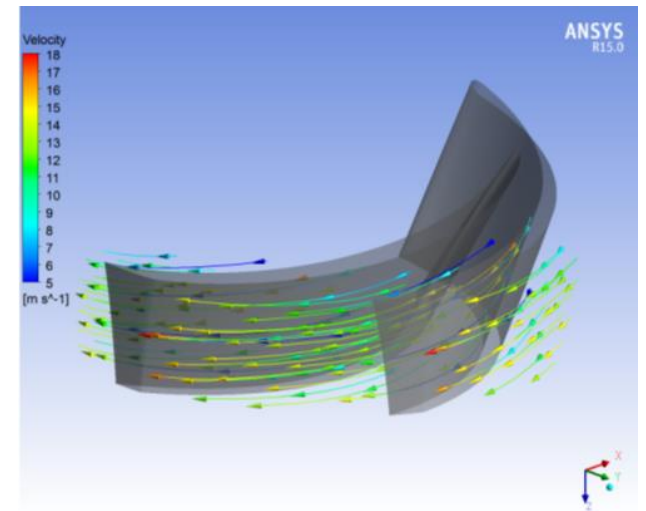

(c)

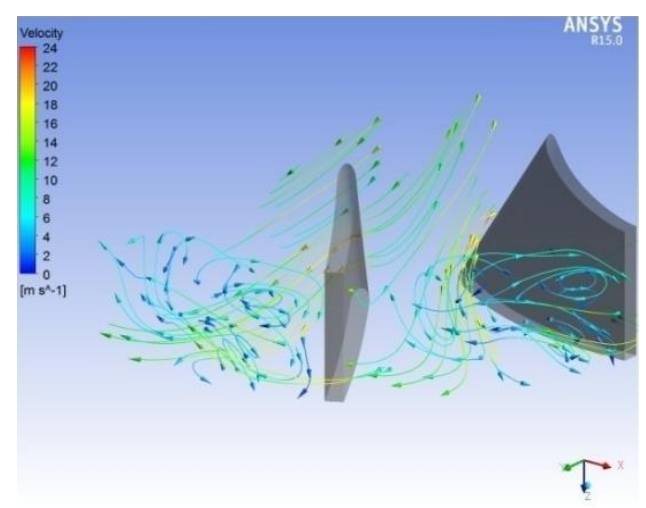

(d)

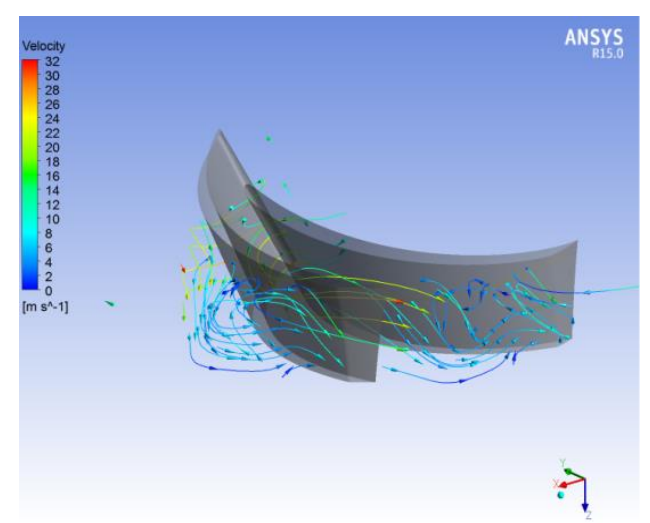

Figure 11. Impeller peripheral velocity: at the angle of the blade: $\quad$ (a) $\beta \pi_{2}=58.18^{\circ} ; \quad$ (b) $\beta \pi_{2}=50.1^{\circ} ; \quad$ (c) $\beta \pi_{2}=90^{\circ}$; (d) $\beta \pi_{2}=121.24^{\circ}$ (a)

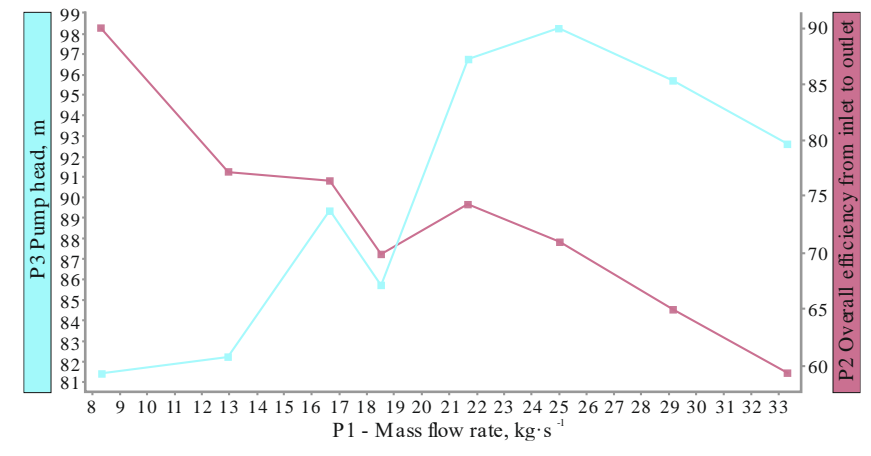

(b)

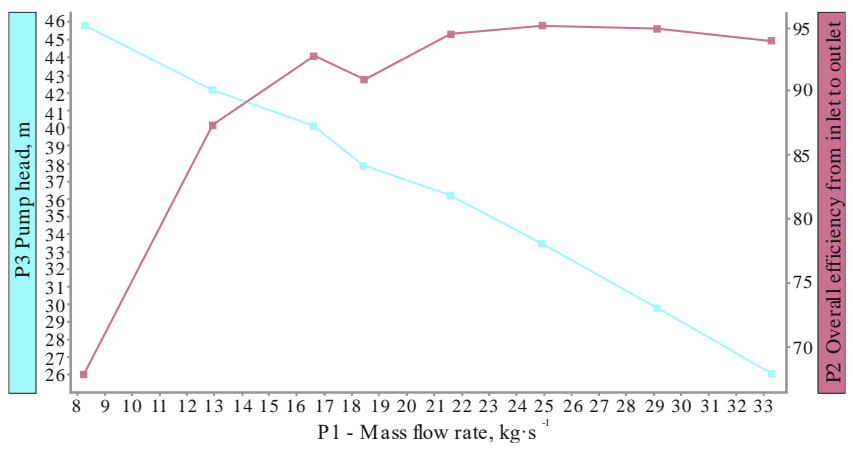

Figure 12. Impeller efficiency graph: (a) blade-outlet angle is $\beta \pi_{2}>90^{\circ}$; (b) blade-outlet angle is $\beta \pi_{2}<90^{\circ}$

The research on the hydrodynamic peculiarities of the diverting device, which influences on the characteristics of the pump, makes it possible to develop impellers that effectively operate in a wide range of delivery rates.

\section{Conclusions}

The conducted research has led to the following conclusions. It has been proven that the main reason for the failure of the flow part components in the dredge pumps is the manifestation of the influence of cavitation processes, which can be eliminated by changing the blade-outlet inclination angles of the impellers.

The developed method for calculating the flow parts of dredge pumps, based on the optimization of algorithms for simulation-mathematical models of the hydrodynamics of viscous fluids using the Ansys software package, can be recommended to design organizations, research institutions and manufacturing enterprises for use in the design, operation and improvement of dredge pumps at the design stage.

The results of research on the optimization of the geometric shape of the dredge pump impellers make it possible to formulate general recommendations for determining a rational number of computational cells for various impeller elements, which is sufficient to solve the problems of determining the optimal parameters of pumps during simulation modeling.

It has been revealed that one of the main factors influencing the developed head of dredge pumps and the value of efficiency is the value of the blade-outlet inclination angle of the impellers. Thus, with the blade-outlet inclination angles $\beta \pi_{2}>90^{\circ}$ (Fig. 12b) with an increase in performance, efficiency decreases (in red), and the head increases (in blue). With the blade-outlet inclination angles of $\beta \pi_{2}<90^{\circ}$, on the contrary, with an increase in performance, the efficiency 
increases, but the head decreases. The low head developed by the hydraulic pump at the inclination angles of the impeller blades $\left(\beta \pi_{2}<90^{\circ}\right)$ is explained by the large values of the relative flow rate on the impeller blades due to the wellstreamlined shape of the blades.

The developed method for calculating the flow parts of pumps based on the use of optimization algorithms and methods of computational fluid dynamics makes it possible to design dredge pumps with optimal characteristics that ensure their efficient operation with maximum efficiency values.

\section{Acknowledgements}

The authors express their deep gratitude to the academic teaching staff of the departments: Mining electrical engineering, Navoi State Mining Institute, Navoiy city, Uzbekistan; Technological machines, transport and logistics, Institute of Metallurgy and Industrial Engineering, Satbayev University, Almaty, Kazakhstan and the administration of the Navoi State Mining Institute for valuable advice and support when using the virtual laboratory setup created on the laboratory base of the institute with the Ansys software package.

\section{References}

[1] Aleksandrov, V.I. (2006). Raschet sistemy gidrotransporta khvostov obogashcheniya zheleznoy rudy na Kachkanarskom GOKe po rezultatam eksperimentov. Sbornik dokladov 13-oy Mezhdunarodnoy konferentsii "Transport $i$ Sedimentatsiya Tverdykh Chastits", 250-263.

[2] Beccati, N., Ferrari, C., Parma, M., \& Semprini, M. (2019). Eulerian multi-phase CFD model for predicting the performance of a centrifugal dredge pump. International Journal of Computational Methods and Experimental Measurements, 7(4), 316 https://doi.org/10.2495/cmemv7-n4-316-326

[3] Zhao, X., Luo, Y., Wang, Z., Xiao, Y., \& Avellan, F. (2019). Unsteady flow numerical simulations on internal energy dissipation for a lowhead centrifugal pump at part-load operating conditions. Energies, 12(10), 2013. https://doi.org/10.3390/en12102013

[4] Peng, G.J., Zhou, G.X., Fu, S.S., Ma, J.F., Huang, X., \& Zhu, Q.J. (2018). Preliminary study on internal flow simulation of centrifugal dredge pump by SPH algorithm. IOP Conference Series: Earth and Environmental Science, (163), 012118. https://doi.org/10.1088/1755$1315 / 163 / 1 / 012118$

[5] Hong, G., Jiang, J., \& Yu, G.L. (2013). Numerical simulation of motion trajectory of sediment particles in dredge pump. Proceedings WODCON XX-Congress and Exhibition: The Art of Dredging

[6] Cao, L., Wang, Z., \& Zheng, L. (2019). Numerical investigation on the head and unsteady flow characteristics of a dredge pump loading highconcentration sands. $22^{\text {nd }}$ World Dredging Congress, 659-667.

[7] Zhao, X., Wang, Z., Xiao, Y., \& Luo, Y. (2019). Thermodynamic analysis of energy dissipation and unsteady flow characteristic in a centrifugal dredge pump under over-load conditions. Proceedings of the Institution of Mechanical Engineers, Part C: Journal of Mechanical Engineering Science, 233(13), 4742-4753. https://doi.org/10.1177/0954406218824350

[8] Duarte Forero, J., Lopez Taborda, L., \& Bula Silvera, A. (2019). Characterization of the performance of centrifugal pumps powered by a diesel engine in dredging applications. International Review of Mechanical Engineering, 13(1), 11-20. https://doi.org/10.15866/ireme.v13i1.16690

[9] Munts, E.A., Dasselaar, S.J., Bugdayci, H., Goeree, J.C., \& Van Rhee, C. Numerical investigation of sand-water mixture behavior in a centrifugal dredge pump. $19^{\text {th }}$ International Conference on Hydrotransport, 29-41.

[10] Bai, Z., Hu, X., Wang, B., Hu, Z., Yang, X., \& Zhao, T. (2020). Optimization of shaft-seal water system of cutter suction dredger based on highefficiency centrifugal separation technology. Separation and Purification Technology, (236), 116267. https://doi.org/10.1016/j.seppur.2019.116267
[11] Peng, G., Wang, Z., \& Fu, S. (2015). Wear characteristics of flow parts of centrifugal dredge pump. Journal of Drainage and Irrigation Machinery Engineering, 33(12), 1013-1018.

[12] Peng, G.J., Luo, Y.Y., \& Wang, Z.W. (2015). Research on wear properties of centrifugal dredge pump based on liquid-solid two-phase fluid simulations. IOP Conference Series: Materials Science and Engineering, 72(4), 042048. https://doi.org/10.1088/1757-899x/72/4/042048

[13] Aref'ev, N.N. (2015). Method for designing the impeller blade for an axial dredge pump. Power Technology and Engineering, 49(3), 186189. https://doi.org/10.1007/s10749-015-0596-0

[14] Bugdayci, H.H., Munts, E., \& Grinwis, H. (2013). Latest developments in dredge pump technology: how recent pump designs can improve the productivity of a dredge, Netherlands. Proceedings WODCON XXCongress and Exhibition: The Art of Dredging

[15] Zhai, L.M., Cao, L., Cao, J.W., Lei, H.M., Ahn, S.H., Chen, F.N., Luo, Y.Y., Xiao, Y.X., \& Wang, Z.W. (2019). Numerical analysis of rotor dynamics of dredge pump shafting. IOP Conference Series: Earth and Environmental Science, (627), 012015. https://doi.org/10.25103/jestr.133.02

[16] Gutierrez, J.C., Ochoa, J.V., \& Forero, J.D. (2020). Parametric analysis CFD of the hydraulic performance of a centrifugal pump with applications to the dredging industry. Journal of Engineering Science and Technology Review, 13(3), 8-14. https://doi.org/10.25103/jestr.133.02

[17] Shuang, J., Fusheng, N., \& Ting, L. (2019). Research on the multi-loop control system for swing process of cutter suction dredger. Proceedings of the $20194^{\text {th }}$ International Conference on Automation, Control and Robotics Engineering. https://doi.org/10.1145/3351917.3351968

[18] Mingming, L., Haifei, Z., \& Tao, G. (2019). Numerical analysis and test of shaft water seal with dredge pump. $22^{\text {nd }}$ World Dredging Congress.

[19] Baranov, Yu.D., Blyus, B.A., Semenenko, E.V., \& Shurygin, V.D. (2006). Obosnovanie parametrov i rezhimov raboty sistem gidrotransporta gornykh predpriyatiy. Dnepropetrovsk, Ukraina: Institut geotekhnicheskoy mekhaniki imeni N.S. Polyakova, $416 \mathrm{~s}$.

[20] Zavertkin, P.S. (2009). Povyshenie resursa gruntovykh nasosov snizheniem intensivnosti gidroabrazivnogo iznashivaniya ikh elementov $v$ sistemakh gidrotransporta khvostov obogashcheniya. Dissertatsiya na soiskanie stepeni kandidata tekhnicheskikh nauk. Sankt-Peterburg, Rossiya, $115 \mathrm{~s}$.

[21] Lomakin, V.O. (2017). Razrabotka kompleksnogo metoda rascheta protochnykh chastey tsentrobezhnykh nasosov s optimizatsiey parametrov. Dissertatsiya na soiskanie stepeni doktora tekhnicheskikh nauk. Moskva, Rossiya, $250 \mathrm{~s}$.

[22] Kharchuk, S.I., Boldyrev, A.V., \& Zhizhin, S.M. (2009). Raschet napornoy kharakteristiki tsentrobezhnogo nasosa chislennym metodom. Vestnik UGATU, 12(2), 51-58.

[23] Bacharoudis, E.C., Filios, A.E., Mentzos, M.D., \& Margaris, D.P. (2008). Parametric study of a centrifugal pump impeller by varying the outlet blade angle. The Open Mechanical Engineering Journal, 2(1), 75-83. https://doi.org/10.2174/1874155x00802010075

[24] Akhras, M., El Hajem, R., Morel, J.Y. (2001). The internal flow investigation of a centrifugal pump. Journal of Visualization, 91-98.

[25] Suhane, A. (2012). Experimental study on centrifugal pump to determine the effect of radial clearance on pressure pulsations, vibrations and noise. International Journal of Engineering Research and Applications, 2(4), 1823-1829.

[26] Peng, G.J., Zhou, G.X., Fu, S.S., Ma, J.F., Huang, X., \& Zhu, Q.J (2018). Preliminary study on internal flow simulation of centrifugal dredge pump by SPH algorithm. IOP Conference Series: Earth and Environmental Science, (163), 012118. https://doi.org/10.1088/1755$1315 / 163 / 1 / 012118$

[27] Aref'ev, N.N., \& Yakovlev, S.G. (1988). Results of studies on a model of an axial-flow pump with screw impeller and hydrodynamic seal. Trudy GIIVT, (231).

[28] Matsumoto, S., Ohba, H., \& Miyamoto, H. (2001). An analysis of flow in a centrifugal impeller by FEM with k- $\varepsilon$ model. Journal of Thermal Science, 10(1), 7-13. https://doi.org/10.1007/s11630-001-0002-0

[29] CFD - BladeGen, Version 3.2. (2000). Users's Guide. AEA Technology Engineering Software Inc.

[30] CFX - TurboGrid, Version 1.5. (2000). Software Documentation, User Manual. AEA Technology Engineering Software, Ltd.

[31] Kurbonov, O.M., \& Atakulov, L.N. (2020). Issledovanie po povysheniyu rabotosposobnosti nasosnogo oborudovaniya. Journal of Advances in Engineering Technology, 1(1), 21-24.

\section{Вибір геометричної форми проточної частини грунтових насосів для в'язких рідин}

\section{Г. Аканова, Л. Сагатова, Л. Атакулов, У. Каюмов, М. Істамов}

Мета. Встановлення можливості підвищення ефективності роботи грунтових насосів для вязких рідин шляхом встановлення раціональних значень вихідних кутів нахилу лопаток робочих коліс насоса. 
Методика. При проведенні досліджень використано теоретичні дослідження структури течії в'язких рідин у проточній частині грунтових насосів; метод тривимірного програмно-імітаційного моделювання гідродинамічних процесів із використанням програмного комплексу Ansys; методику раціонального планування експерименту для вибору значень числа вузлів розрахункової сітки при оптимізації геометричних параметрів робочих коліс грунтових насосів; методи математичної статистики і кореляційного аналізу.

Результати. Доведено, що основною причиною виходу з ладу деталей проточної частини грунтових насосів $\epsilon$ прояви впливу процесів кавітації, які можуть бути усунені зміною кутів нахилу лопаток робочих коліс на виході. Розроблено програмноімітаційний комплекс автоматизованого проектування проточних частин грунтових насосів на основі застосування оптимізаційних алгоритмів та методів обчислювальної гідродинаміки, який дозволяє проектувати грунтові насоси з оптимальними характеристиками, що забезпечують ефективну їх роботу з максимальними значеннями ККД. Встановлено, що одним з головних факторів, що впливають на створюваний натиск грунтовими насосами і значення ККД, є величина вихідного кута нахилу лопаток робочих коліс.

Наукова новизна полягає в науковому обгрунтуванні та розробці імітаційно-математичного методу розрахунку геометричних параметрів проточної частини грунтових насосів для в'язких рідин на етапі їх проектування.

Практична значимість. Розроблений метод встановлення раціональних вихідних кутів нахилу лопаток робочих коліс грунтових насосів для вязких рідин може бути рекомендований проектним, науково-дослідним і промисловим організаціям для використання при вдосконаленні, проектуванні та експлуатації грунтових насосів.

Ключові слова: гідравлічний транспорт, трунтовий насос, робоче колесо, лопата, знос, статичний тиск

\section{Выбор геометрической формы проточной части грунтовых насосов для вязких жидкостей}

\section{Г. Аканова, Л. Сагатова, Л. Атакулов, У. Каюмов, М. Истамов}

Цель. Установление возможности повышения эффективности работы грунтовых насосов для вязких жидкостей путем установления рациональных значений выходных углов наклона лопаток рабочих колес насоса.

Методика. При проведении исследований использованы теоретические исследования структуры течения вязких жидкостей в проточной части грунтовых насосов; метод трехмерного программно-имитационного моделирования гидродинамических процессов с использованием программного комплекса Ansys; методика рационального планирования эксперимента для выбора значений числа узлов расчетной сетки при оптимизации геометрических параметров рабочих колес грунтовых насосов; методы математической статистики и корреляционного анализа.

Результаты. Доказано, что основной причиной выхода из строя деталей проточной части грунтовых насосов являются проявления воздействия процессов кавитации, которые могут быть устранены изменением углов наклона лопаток рабочих колес на выходе. Разработан программно-имитационный комплекс автоматизированного проектирования проточных частей грунтовых насосов на основе применения оптимизационных алгоритмов и методов вычислительной гидродинамики, который позволяет проектировать грунтовые насосы с оптимальными характеристиками, обеспечивающих эффективную их работу с максимальными значениями КПД. Установлено, что одним из главных факторов, оказывающих влияние на развиваемый напор грунтовыми насосами и значение КПД, является величина выходного угла наклона лопаток рабочих колес.

Научная новизна заключается в научном обосновании и разработке имитационно-математического метода расчета геометрических параметров проточной части грунтовых насосов для вязких жидкостей на этапе их проектирования.

Практическая значимость. Разработанный метод установления рациональных выходных углов наклона лопаток рабочих колес грунтовых насосов для вязких жидкостей может быть рекомендован проектным, научно-исследовательским и промышленным организациям для использования при совершенствовании, проектировании и эксплуатации грунтовых насосов.

Ключевые слова: гидравлический транспорт, грунтовой насос, рабочие колесо, лопасть, износ, статическое давление 